\title{
Notes on the adaptation of some phytophagous and predacious mites to various ecological parameters in the Mediterranean countries
}

\author{
S. Ragusa and H. Tsolakis
}

\begin{abstract}
Ragusa, S. and Tsolakis, H. 2000. Notes on the adaptation of some phytophagous and predacious mites to various ecological parameters in the Mediterranean countries. Web Ecol. 1: 35-47.
\end{abstract}

\begin{abstract}
Notes on the adaptation to various habitats, climatic conditions, life-cycles, dispersion as well as on some morpho-physiological ones of the main phytophagous (Tetranychidae and Eriophyidae) and predaceous (Phytoseiidae) mites typical of the Mediterranean area are reported in the present paper.
\end{abstract}

S. Ragusa (ragusa@unipa.it) and H. Tsolakis, Istituto di Entomologia agraria-Viale delle Scienze, I-90128 Palermo, Italy.

The subclass of mites includes different organisms which contribute to create a kaleidoscope of different shapes, nutritional regimes, behaviours, and habitats. Their size may vary from some centimeters to $<100 \mu \mathrm{m}$. They have colonised almost every place on the earth including some water habitats. However, despite their ubiquity, they remained almost unknown until the end of 19th century. Afterwards, due to their negative action against mankind and because of the use (or abuse) of chemicals (such as phosphoric compounds), the world of these small arthropods started to be considered, and scientists tried to deepen their knowledge on them mainly because of their ecological and economical importance.

The mites' microcosmos includes species which are zoophagous, phytophagous, omnivorous, and saprophagous (Evans 1992), most of them typical of the Mediterranean habitats. Such nutritional diversification implies different ways of life followed by a variety of structural and nonstructural adaptations (biological cycles, climatic adaptations, etc.).

In the present paper we will try to show some of these adaptations, mainly the morphological ones to different nutritional regimes, those functional to the defence of the species against predators and climatic adversities as well as the adaptation to different macro- and micro-climatic conditions of the main phytophagous (Tetranychidae, Eriophyidae) and predaceous (Phytoseiidae) species of mites typical of the Mediterranean environment.

\section{Nutritional adaptation}

The species which we will take into account are associated with both agricultural and wild plants and interfere both directly and indirectly on their physiology. The large number of species, present on plants, undertake different roles which vary from a simple presence to a more or less direct relationship with the plant.

However, before starting to talk about the capability of various species to adapt and live on different plants or prey, we must show the modifications and adaptations that the gnathosoma (or mouth parts) has passed through within the various families. 


\section{Adaptation of mouth parts to various diets}

The gnathosoma of mites is formed by three main parts: chelicerae, subcapitulum, pedipalps. The chelicerae were originally formed by an articulated pole and by a chela with a movable and a fixed digit. These were deeply modified in tetranychid mites to be adapted to phytophagy: the movable digits were transformed into two cheliceral stylets (Fig. 1) which hook up during protrusion forming an efficient piercing structure and delimiting an internal duct which is considered as a salivary duct (Alberti and Crooker 1985, Nuzzaci and De Lillo 1991) (Fig. 2). In the pedipalps the tibia has claws used for tearing the cells' walls of the plant tissues. Moreover, the silk producing glands, in the pedipalps, are present in the species which produce silken threads (Fig. 3).

The mouth parts of Eriophyoidea are made by a higher number of stylets or stylet-like structures (deriving from chelicerae and other mouth parts) whose number ranges from 7 to 9 , and by reduced palps which, together with the stylet sheath, enclose and direct the stylets in piercing the plant surface (Nuzzaci 1979, Lindquist 1996, Nuzzaci and Alberti 1996).

Mouth parts of predaceous mites, especially phytoseiid mites, are adapted to predation, almost maintaining their original ancestral structure. Palps are sensorial organs which help mites to locate the prey and may be used to get the prey near the mouth later on. Chelicerae maintain a strongly sclerotised chela (Fig. 4) which can be more or less elongated with a variable number of teeth according to the food type. Two highly sclerotised and pointed structures called corniculi are also present at the tip of subcapitulum and they are used to impale prey and to enlarge the

Fig. 1. Lateral view of the gnathosoma of Tetranychus urticae

(Koch). wounds caused by chelicerae (Fig. 5). According to Evans and Till (1965) and Krantz (in Flechtmann and McMurtry 1992), the function of the corniculi is to supporte and guide the salivary styli. The subcapitulum has a conic shape (Fig. 5) to help, according to Akimov and Starovir (1978) its introduction inside the body of victims.

Light modifications of the mouth parts may be noted in some phytoseiid species which can be considered as adaptations to prey or to the habitat where the prey lives. As an example we consider Paragigagnathus tamaricis (Amitai and Grinberg), described from material collected on Tamarix maris mortui in Israel which shows thinner and more elongate gnathosoma, chelicerae and pedipalps (ratio base of gnathosoma/pedipalp $=8.7$, ratio pedipalp/chelicera $=1.9$, ratio pedipalp/leg $I=0.9)$ if compared to those of other phytoseiids (ratios 1.9, 1.5, 0.5 respectively) (Fig. 6). The chelae are also thinner and elongate and have few teeth and only on their distal part. As a matter of fact, the species bred in laboratory trials lived exclusively preying upon a tenuipalpid mite, Obdulia tamaricis (Pritchard and Baker), a gall making species (Amitai and Grinberg 1971). The predator could use the elongation of both chelicerae and pedipalps to catch prey by introducing its gnathosoma in the restricted spaces of galls, using the pedipalps to put out prey and the chelicerae to catch and break their teguments.

Typhlodromus longipalpus (Swirski and Ragusa) described from material collected on Cupressus in Greece, has also elongate chelicerae and pedipalps (ratio palp/chelicera $=1.75$, ratio palp/legI $=0.77$ ). The species, has been found up to now, on forest plants in different parts of Greece (Ragusa Di Chiara et al. 1995). The chelicera and pedipalps in this species have, most probably, a similar function to that hypothesized for $P$. tamaricis.

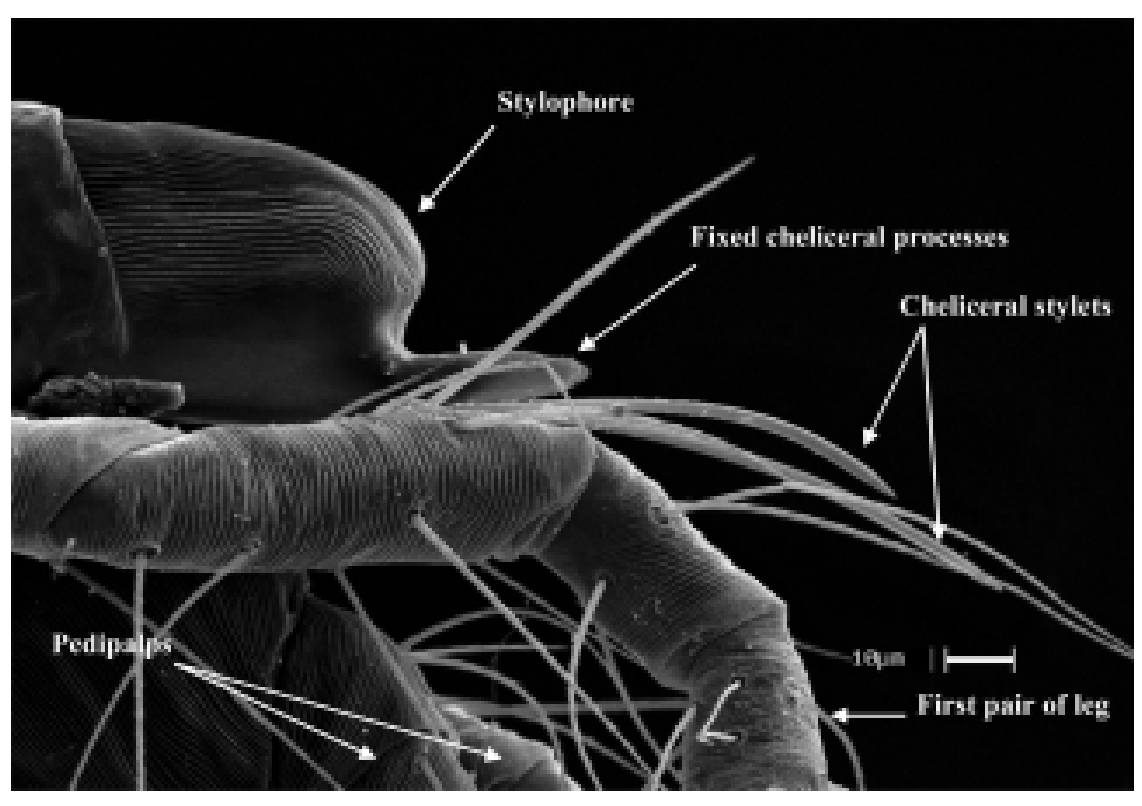


Fig. 2. Distal part of a cheliceral stylet of Tetranychus urticae (Koch).

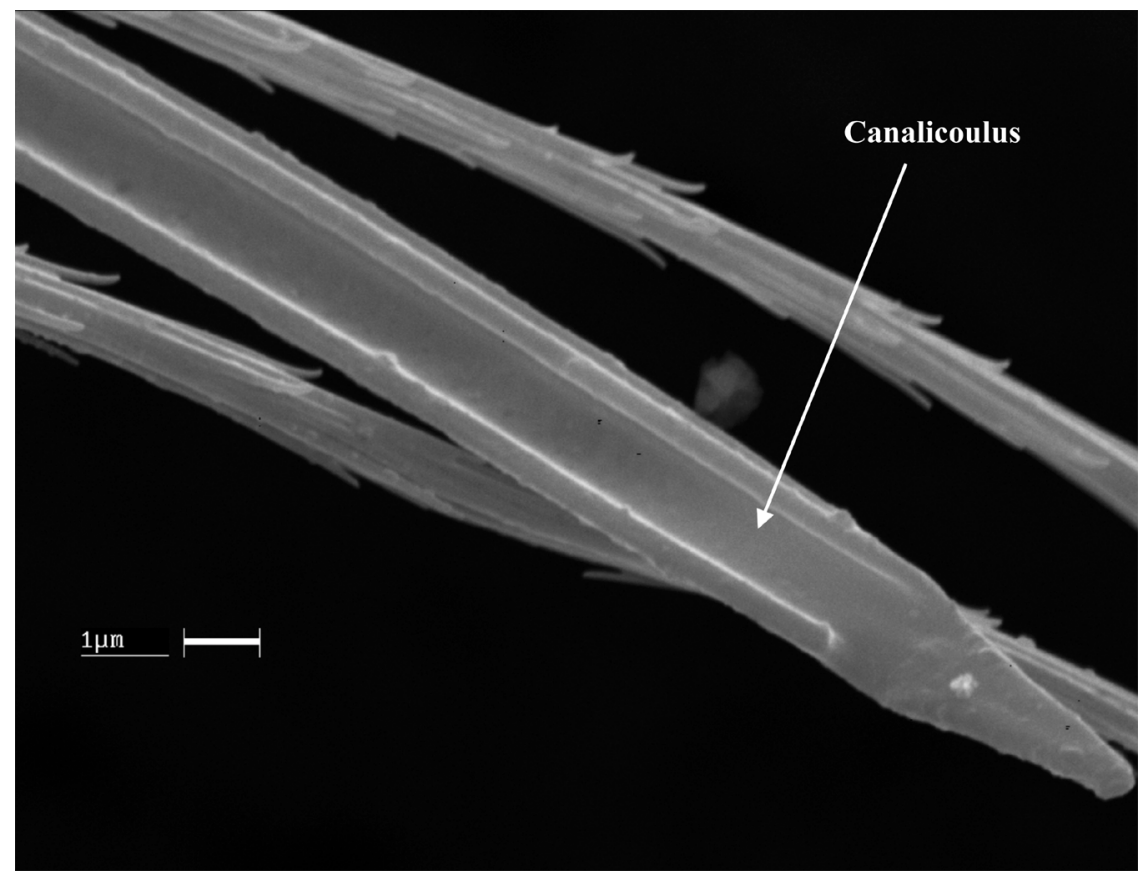

\section{Physiological adaptations}

Besides the adaptation of the gnathosoma towards different types of food, a serious of physiologiacal adaptations concerning the digestive system is also present. According to these modifications the phytophagous species could be distinguished into monophagous, oligophagous and polyphagous, while the predaceous ones can be divided into obligatory, generic and generic facultative. The most abundant number of monophagous species are found among the Eriophyoidea which show a coevolution together with the plant with great inner and outer transformations of the mite. Species which cause distortions on plants (galls, erinea, etc.) produce toxic materials favouring the appearence of particular structures within which mites find shelter and a large surface of abundant tender tissue
Fig. 3. Pedipalpal tarsus of Tetranychus urticae (Koch).

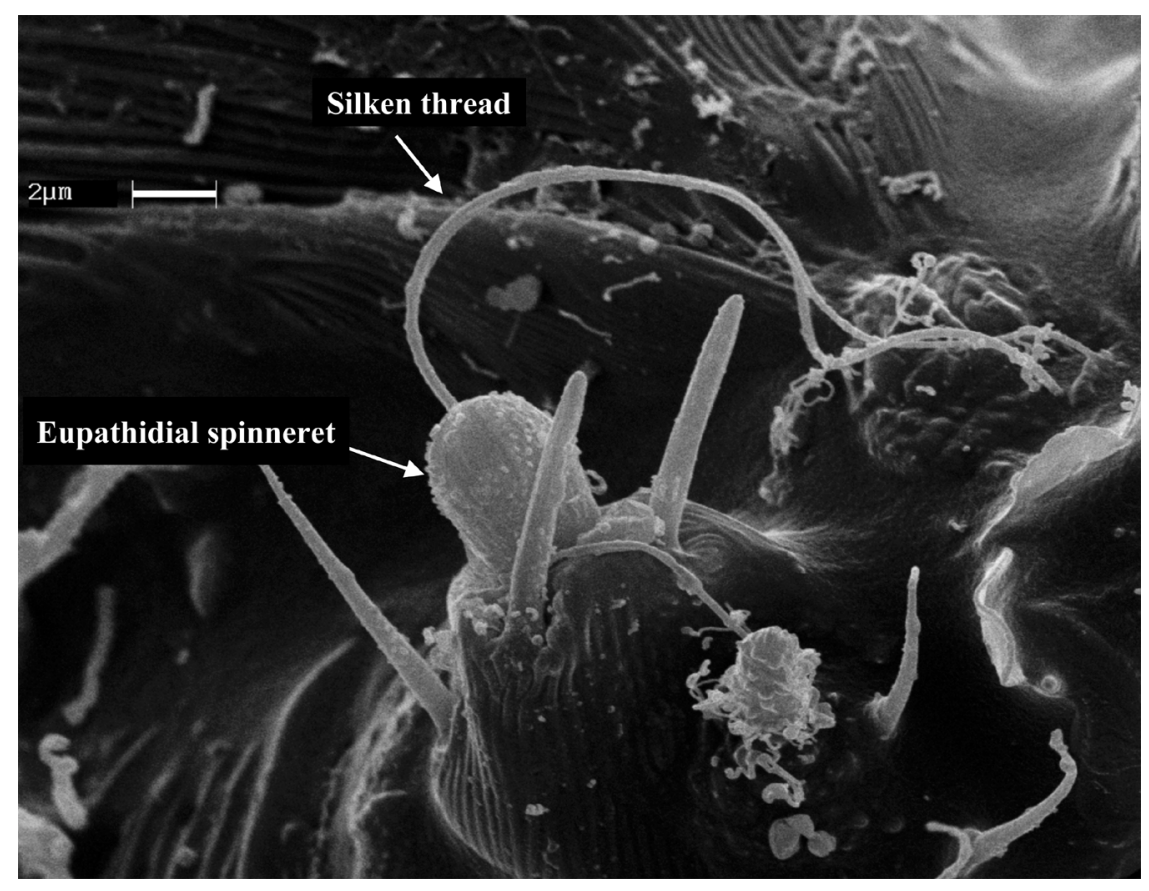




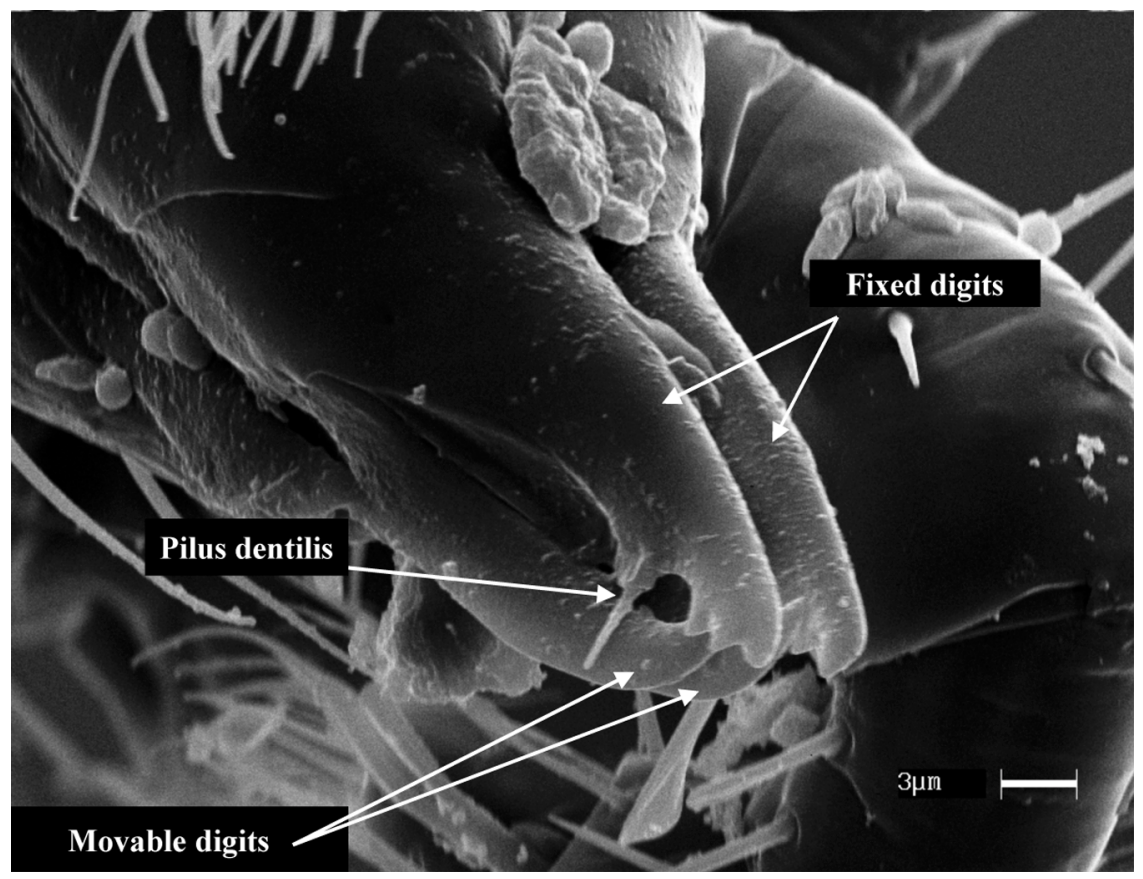

Fig. 4. Chelicerae of the phytoseiid mite Typhlodromus rhenanoides (Athias-Henriot).

which is very satisfactory as food. In such a case mites are strictly linked to the plant as the toxic materials introduced by the species cause the formation of galls and acarocecidia only on certain determined plants.

The geographic distribution of mites is strictly linked to the distribution of the host plants. In these cases the climatic limits of the distribution of the mite species coincide with those of the host plant.
Oligophagous species, as with the preceding ones, are able to establish an equilibrium ratio with the host plants causing only minor damage which usually do not compromise the well-being of the host. Such species are usually not very specialised and the balance they achieve with the host plant takes its origin mostly from the limited capacity that the species has to spread out in the surroundings. Among such species we find the citrus red mite Panonychus

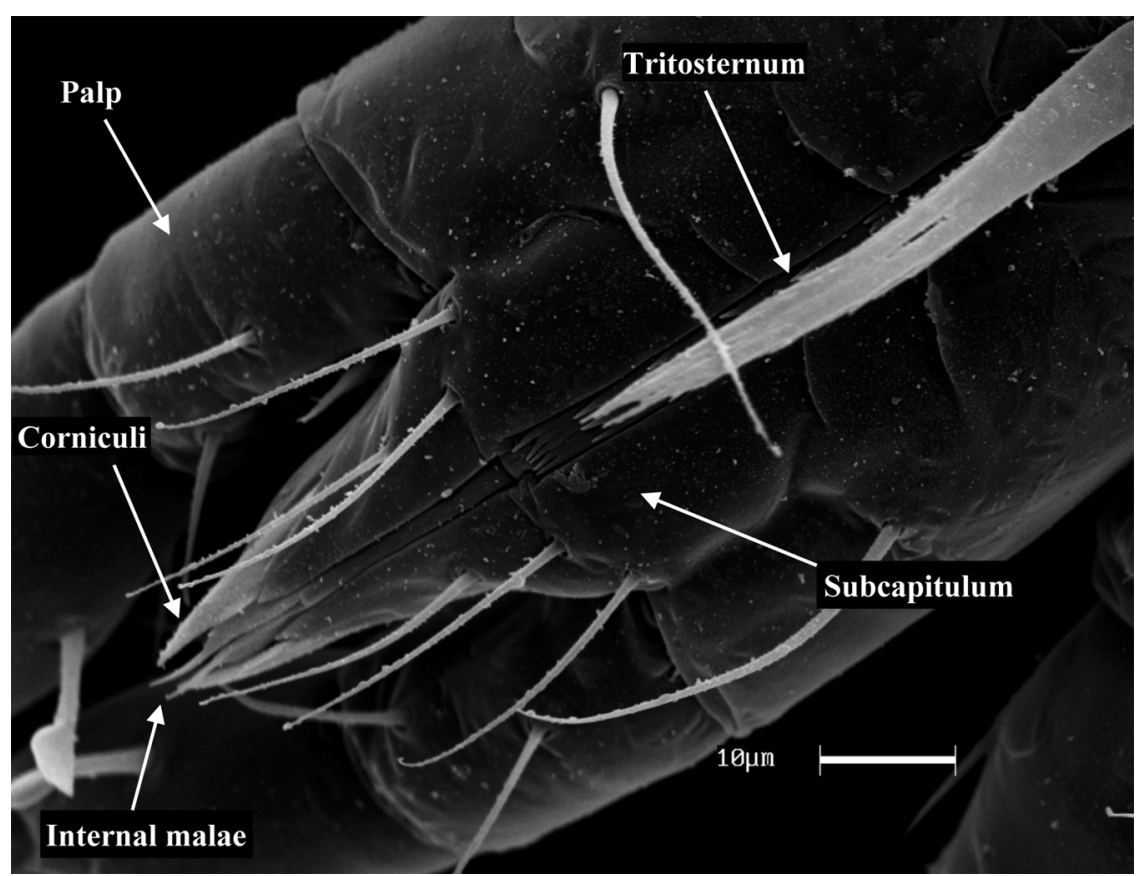

Fig. 5. Ventral view of the gnatosoma of the phytoseiid mite Typhlodromus exhilaratus (Ragusa). 
Fig. 6. Chelicera and pedipalps of Paragigagnathus tamaricis (Amitai and Grinberg) (A) and Cydnodromus californicus (McGregor) (B) (original drawing).

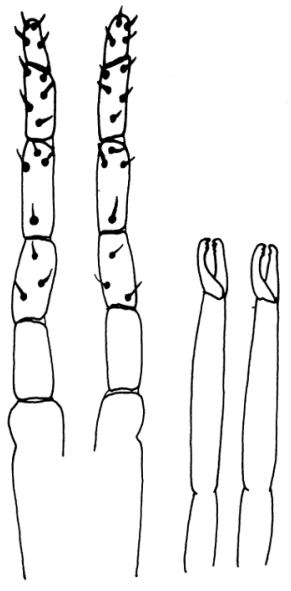

A

citri (McGregor), mainly linked to Citrus spp. (even if sometimes it is also found on almond, nut, pear, and wild Draceae), and Petrobia hartii (Ewing). The latter, common on Oxalis spp. in Sicilian and Spanish citrus orchards (unpubl., Garcia-Marì and Del Rivero 1982), shows a remarkable adaptation to the annual cycle of the host plant, spending its life in summer time (the dry season) on aestivating bulbs of the plant (Gutierrez and Helle 1985).

Finally polyphagy, at least among mites, can be considered as a winning adaptation as it offers greater possibilities of survival during dispersion, which is mostly passive for mites. The two spotted spider mite Tetranychus urticae (Koch), a highly polyphagous species in the Mediterranean regions, seems to be more linked to herbaceous plants (nettle, field bindweed) or shrubby ones (castor bean) than to arboreal plants, while the species damages the majority of cultivated plants (both arboreal, shrubby and herbaceous) in agro-ecosystems. Such a great susceptibility is most probably due to the ecological characteristics of the agroecosystem (non resistant species, use of abundant nitrogenous fertilizers, elimination of useful natural enemies by means of chemical sprayings).

As far as predaceous mites are concerned, they are distinguished in: 1) obligatory predators when they live by preying upon one or a few species of mites belonging to the same family, 2) generic predators when they live on different species belonging to different families, and 3) facultative generic predators when they live on different kinds of prey (insects, mites) and non-prey food (pollen, hyphae or spore, honeydew, etc.). These predaceous phytoseiid mites have big and well developed salivary glands (Nuzzaci et al. 1999). As soon as the body of the prey is penetrated by chelicerae, these glands, through the salivary styli, injects a saliva containing proteolytic enzymes assuring the dissolving of all the body contents (Starovir 1973, Flechtmann and McMurtry 1992, Nuzzaci et al. 1999). The oesophagous structure is similar to that of gamasid blood sucker mites through which the haemolymph passes from the body of the victim after the extraintestinal digestion (Starovir 1973). Among phytoseiid mites, however, circular constrictor muscles have been found in the oesophagous in contrast to gamasid blood suckers: this fact can be considered as an adaptation to a kind of more viscous food or to food which contains harder particles (Akimov and Starovir 1978).

The most important species of the first group is Phytoseiulus persimils (Athias-Henriot) which preys mainly upon T. urticae and occasionally upon $P$. citri. Its digestive system shows some morpho-physiological modifications showing a deep adaptation of the species to predation (Akimov and Starovir 1978). The above authors compared the digestive system of Ph. persimilis to that of two species of facultative generic predators, Amblyseius andersoni (Chant) and Amblyseius reductus (Wainstein), and they found great morphological and functional differences between the two categories of predators. Phytoseiulus persimilis has only two posterior diverticula, while there are four in the other species (Fig. 7). Such a decrease is considered as an adaptation to specialised predation used to increase the amount of ingested food, exploiting the volumetric capacity of intestine to its utmost (Akimov and Starovir 1978). It was suggested that such changes are linked to functional modifications of the epitelial cells of the ventriculus; in fact, in Ph. persimilis these cells remain tied to the basal membrane, pouring their secretion into the intestinal lumen, allowing a very quick digestion of the swallowed food. By contrast, the epitelial cells (both the undifferentiated young and the ripe ones) in a facultative generic predator come out from the basale membrane and are mixed with the food in the intestinal lumen causing a slower digestion (Akimov and Starovir 1978). 


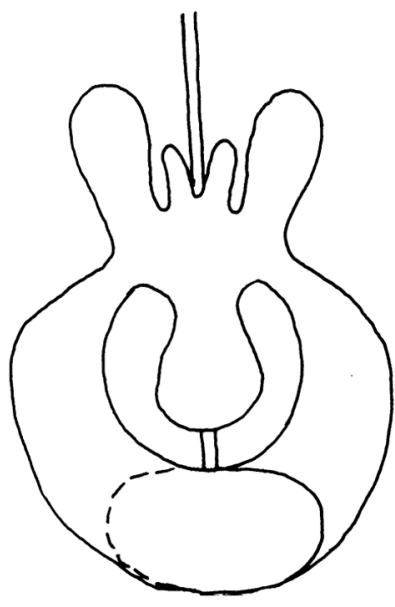

A

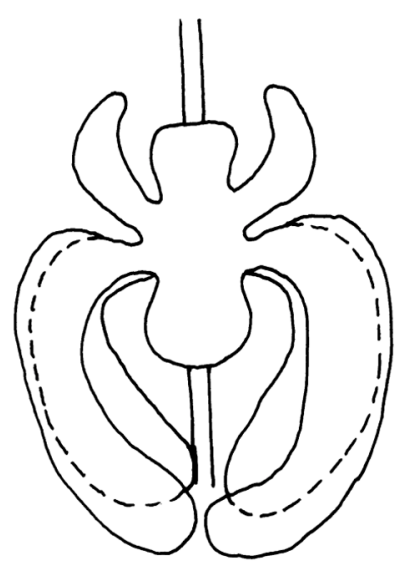

B
Fig. 7. Schematic drawings of diverticula in Ph. persimilis (A) and A. andersoni (B) (from Akimov and Starovir 1978, modified).

\section{Adaptations to habitats}

Tetranychus urticae shows different adaptability characteristics to habitats. This species adapts itself to live on the lower surface of leaves where it sets up strongly crowded colonies protected by a complicated web. The production of silken threads is, on the other hand, peculiar to Tetranychus genus while it is less evident in other genera such as Panonychus and it is completely absent in others, as in some Bryobinae. The production of abundant silken threads, which cover the colony, shows an adaptation mainly with a double protective purpose: 1 ) a physical protection against predators, as the web forms a difficult barrier to be penetrated; it is often possible to see phytoseiid mites and other predators trapped in the web and dead; it also gives a protection against strong rain, 2) a climatic protection as allowing a particular microclimate to be present inside the colony which positively influences the development of the mites especially for the egg's eclosion as their chorion is very "delicate" (Hazan et al. 1974). Moreover T. urticae has adapted to living on the lower surface of leaves to hold new ecological niches, reducing the interspecific competition consequently. Another benefit is linked to protection against various predators which, of course, move more slowly for gravity problems. On the contrary some less evolved species of the same family, tend to live in a solitary way, mainly on the upper surface of the leaves, spinning very few silken threads, ovipositing eggs with a harder chorion directly on the surface and anchoring them with few silken threads (guy ropes) (Saitô 1983).

Mites belonging to Bryobinae family are considered as less evolved Tetranychoidea. They mainly remain on the upper surface of the leaves, exposed to all the negative weather conditions (rain, sun, etc.). They are more easily preyed upon and have to protect themselves and their eggs, and should be able to escape; indeed their legs are particularly elongate. As far as the relationship of these mites with plants is concerned, they do not usually kill their host plants as their ability to disperse is limited and local extinction is a continuous threat (Gutierrez and Helle 1985).

\section{Body adaptations}

The adaptations of the mites' bodies are due more to the habitats where they live and where they get their food than to food type.

The body shape of tetranychid mites is similar to that of free living mites, but some differences in the structure of the tegument are evident. This last one is thin, flexible and transparent (Blauvelt 1945) and usually finely striated and according to Crowe (1975) the striae (ridges) make the cuticle more rigid. On the other hand, the striae are absent in Bryobinae, but a thicker cement layer is present (Pal 1950). Setae are also inserted in the tegument in a different way, in accordance with the life style of the mites. Therefore, setae on the dorsal side of species living in colonies covered by abundant webs (i.e. T. urticae) are thin, serrated, and inserted directly on the tegument, while setae of the species "freely" living on the surface of the leaves are thicker, and inserted on tubercles. These characteristics, as stated above, show evidence of the various adaptions of mites for their protection.

As regards eriophyoid mites, their ancestors have adapted themselves to live in very narrow places such as crevices, or among the perules or in the axilles of monocotyledonous evergreen plants or of graminae. As regards further adaptations which brought to the rise of two types of eriophyids (gall making and vagrant), we report a concise outline of the theory by Lindquist and Oldfield (1996) in Fig. 8. 
Fig. 8. Concise outline of the evolutionary trend of eriophyid mites.

\begin{tabular}{|c|}
\hline $\begin{array}{c}\text { Adaptation to living inside natural cavities, i.e. axils, sheaths, scales and buds of evergreen monocotyledonous } \\
\text { plants }\end{array}$ \\
Elimination of the two pairs of hind legs \\
Abbreviated life cycle (only two immature stages)
\end{tabular}

Elimination of the two pairs of hind legs

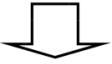

Adaptation to living on dicotyledonous deciduous plants Appearance of a morphologically and physiologically distinct deutogyne form able to overwinter.

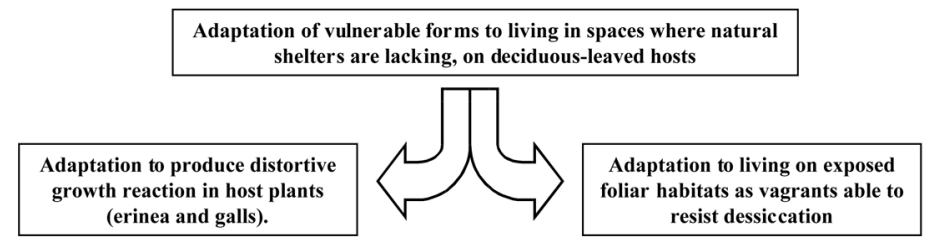

The species of these two lineages have undergone some modifications in the shape of their bodies which can be distinguished mainly in vermiform species (species living in narrow spaces such as galls, erinea, buds) and fusiform species (species living in open spaces). The vermiform mites have a flexible, elongated, non-arcuated aspect, often with many narrow annuli (Fig. 9). The prodorsal shield in these mites is not well-developed and the gnathosoma appears prognathous while the fusiform species have a more developed prodorsal shield and the gnathosoma is ipognathous. The latter have also a more arcuated body and show a series of thicker and less flexible annuli on the dorsal part (Fig. 10) while the ventral annuli remain narrow and flex- ible. This type of dorsal annuli called also "tergites" protect mites against loss of water and predation. In some species they are covered by wax or long wax filaments which give a further protection against loss of water (Fig. 11) (Lindquist 1996).

If we consider now predaceous mites and phytoseiids in particular, only a few examples of body adaptation to nutrition and to special weather conditions can be shown.

The dorsal side of a phytoseid shows a more or less chitinized dorsal shield. Three chitinized plates are visible on the ventral side of females while two plates are present on the ventral side of males. The remaining part of the idiosoma is covered by a cuticle showing some folds which
Fig. 9. A “vermiform” eriophyid mite (Phytoptus avellanae (Nalepa)).

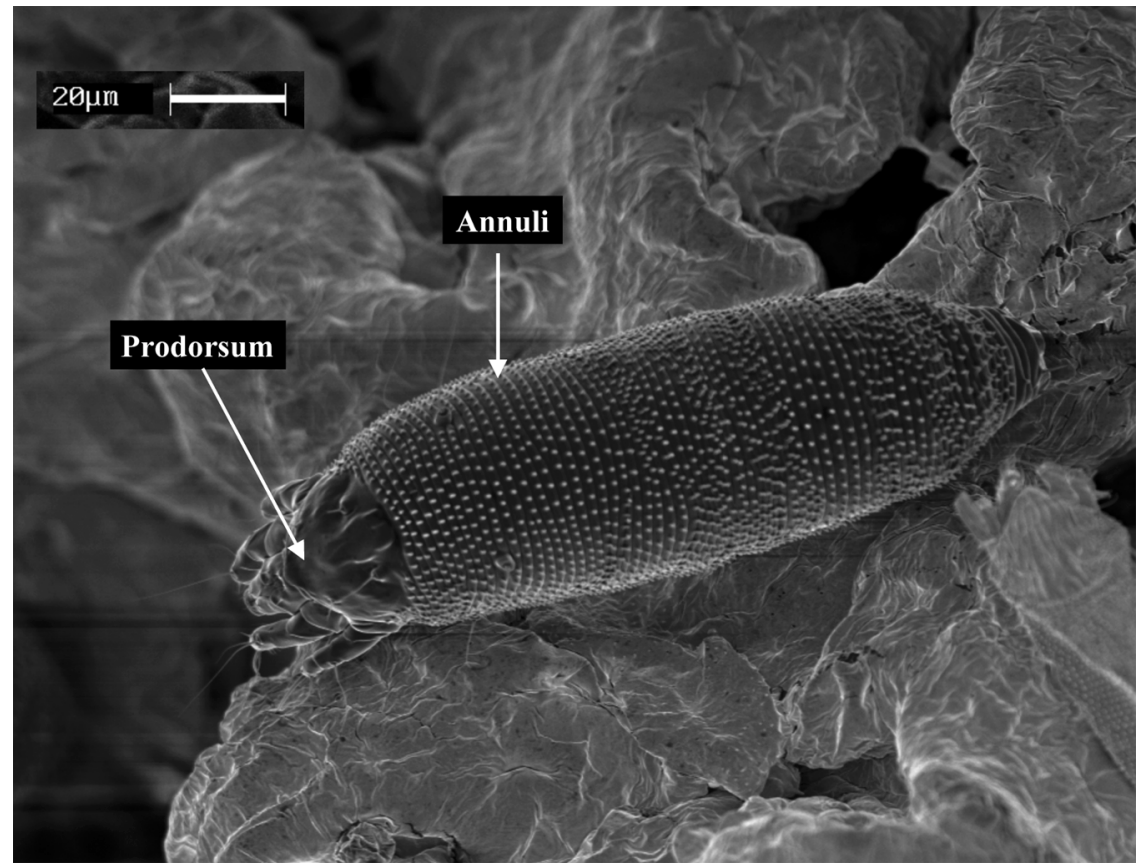



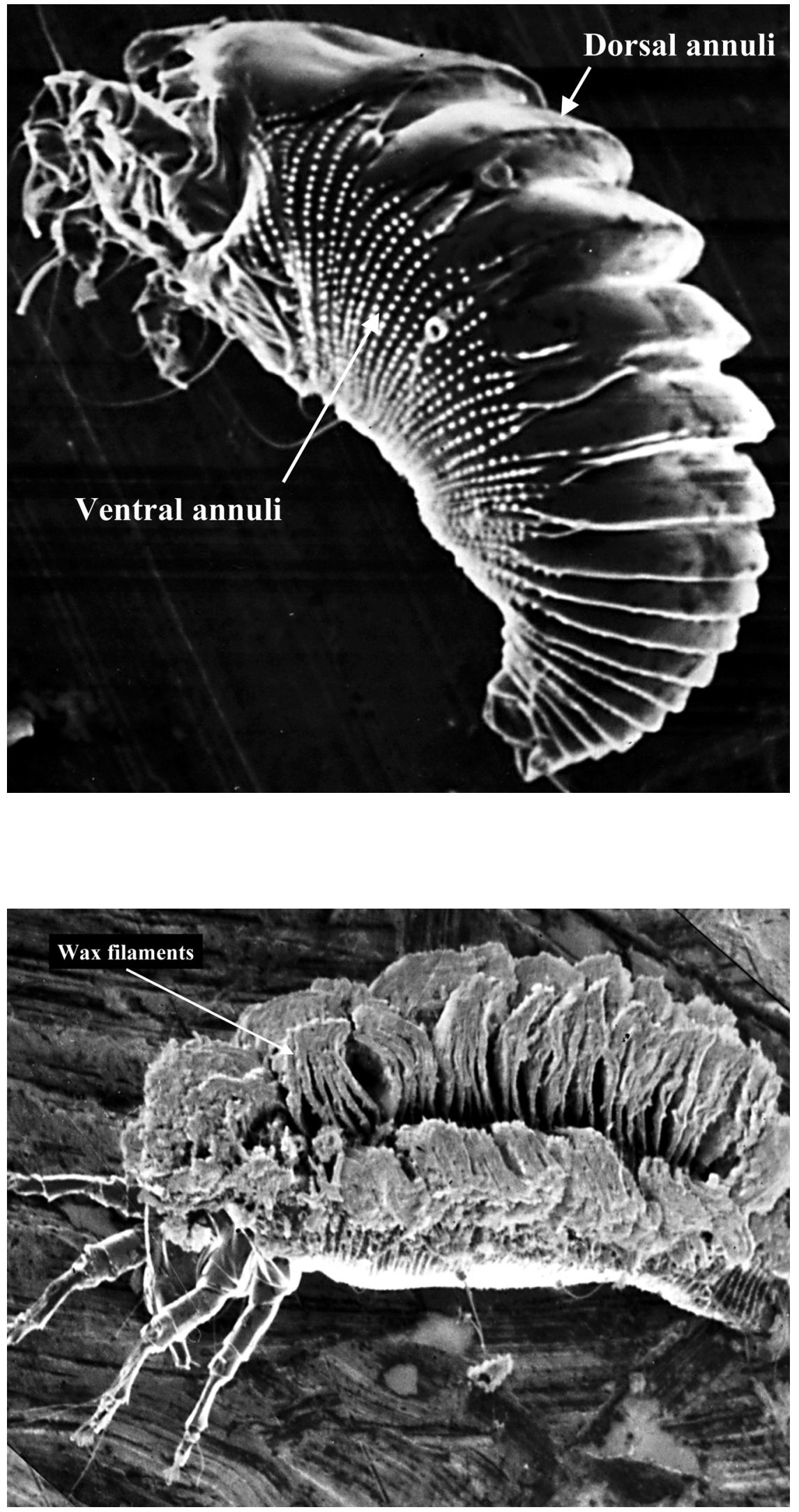

Fig. 10. A "fusiform" eriophyid mite Coptophylla lamimani (Keifer) (courtesy of De Lillo).
Fig. 11. A "fusiform" eriophyid mite, Diptacus sacramentae (Keifer) (courtesy of De Lillo). 
allow extending movements of the body (Fig. 12). The chitinized plates in $\mathrm{Ph}$. persimilis are reduced, if compared to the mite dimension, allowing the increase of the volume of their bodies to store a greater food amount in their intestine. Such a possibility is obviously reduced in species such as Iphiseius degenerans (Berlese) where the dorsal shield covers the whole dorsal surface and parts of the lateral one. We can also mention some of the habitat or nutrition adaptations sensu latu. The long setae present on tarsi of $P h$. persimilis and its long pretarsi might be the adaptation of the species to the habitat where its prey, T. urticae, lives. Such abundant, long and pointed setae are similar to those present on the legs of prey and would suggest a positive action on the movements of the predaceous mites on and among the web produced by the twospotted spider mite. These setae are shorter in other phytoseiid mites unable to walk on the web.

On the other hand the long and serrate setae on dorsal shield of Ph. persimilis (Fig. 13), could be used by the mite as a wedge to raise the silken threads in the sticky web during forward locomotion (Sabelis 1981) to enter the colony of the tetranychid better, avoiding in such a way being caught by the web; or most probably also to cut silken threads. On the other hand species with short dorsal setae do not enter the colonies of the two-spotted spider mite even if the predator is attracted by the prey (Takafuji and Chant 1976). This is the case of $I$. degenerans which prefers living associated with $P$. citri, whose infestation it is able to control (unpubl.).

\section{Adaptations of life cycle}

The post-embryonic development of mites is quite short if the climatic conditions are favourable. It averages ca $10 \mathrm{~d}$ among phytophagous mites, particularly $T$. urticae or $P$. citri, and it is shorter among predaceous mites ( $3-8 \mathrm{~d})$. It appears that predators reduced their cycles in comparison to those of prey mainly for two reasons: 1) to have at their disposal the biggest number of eggs and of young stages of the prey which are the most suitable and the simplest source of food for them and 2) as the young stages of the predators are less active than adults in looking for prey, the shortening of the cycle gives them a bigger opportunity of surviving. Moreover most phytoseiid larvae do not feed to become protonymphs (Ragusa 1979). This behaviour can be also considered an adaptation as hexapode larva is not as active as the following stages (octapode) for food research.

Moreover some phytoseiid mites are better adapted and prefer some foods in comparison to others. As a matter of fact, Chant (1959) found out that Typhlodromus pyri (Scheuten) developed more quickly on the eriophyid Aculus schlechtendali (Nal.) than on Panonychus ulmi (Koch) while $A$. andersoni developed quicker on pollen of Papaver rhoeas than on the different stages of T. urticae (Tsolakis and Ragusa Di Chiara 1994). We can find also similar adaptations to different kind of foods in some tetranichid species. Tetranychus urticae for example prefer the bean plants to tomato while T. cinnabarinus prefers cucumber to tomato (Witul and Kielkiewicz 1999).
Fig. 12. Detail of interscutal membrane in Phytoseiulus persimilis (Athias-Henriot).

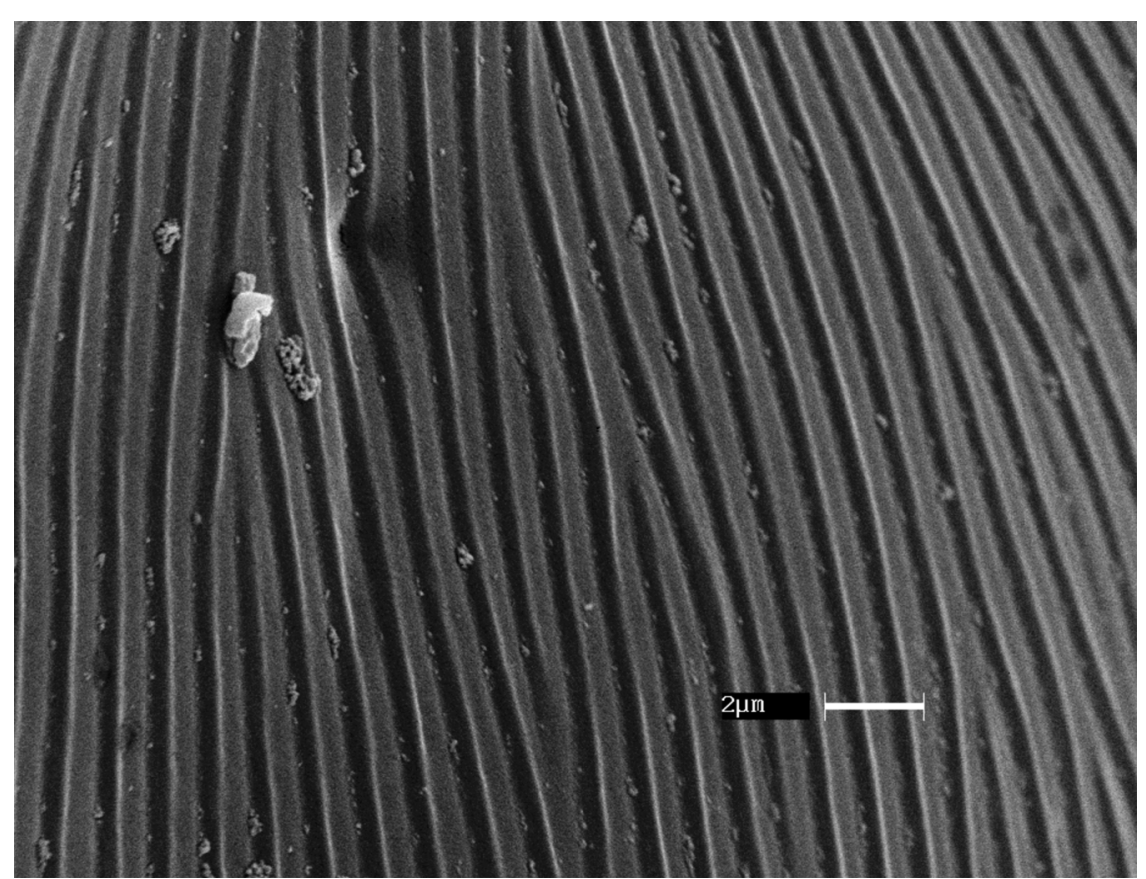




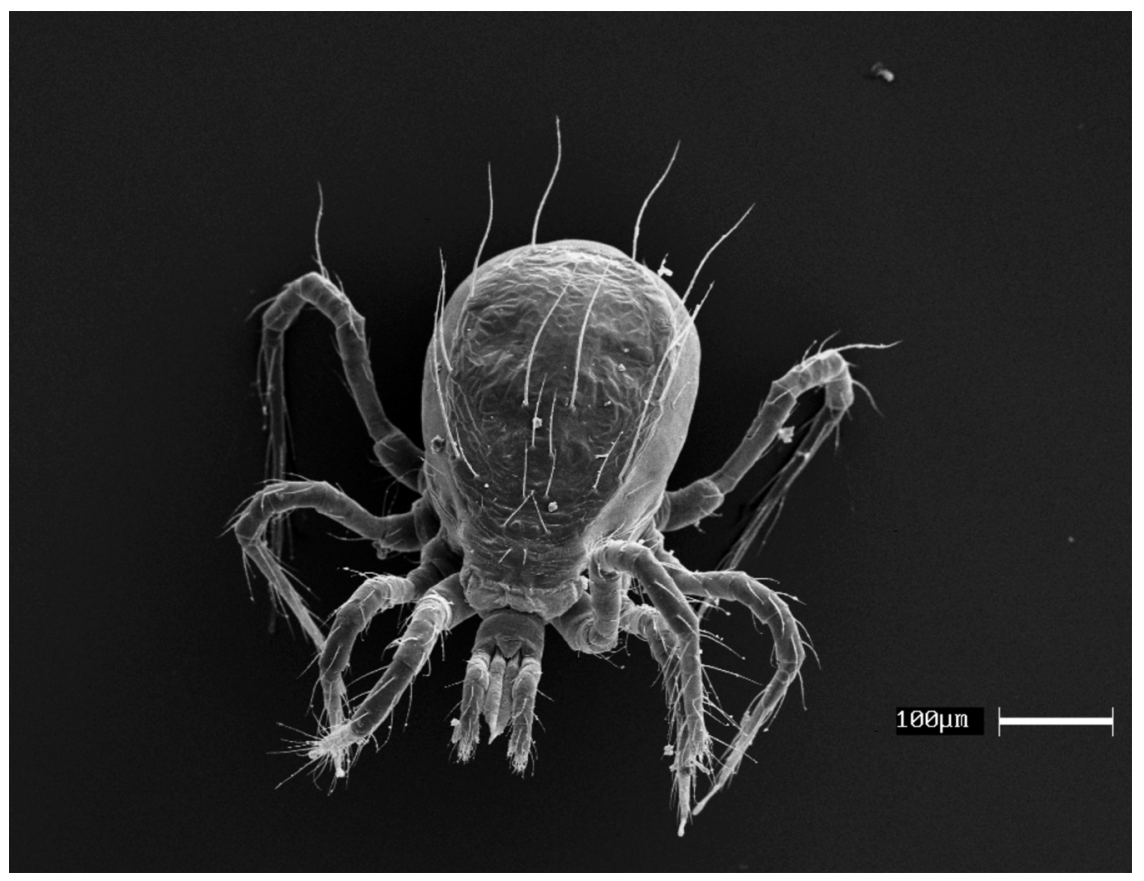

Fig. 13. Dorsal view of Phytoseiulus persimilis (AthiasHenriot).

Phytoseiid mites show also adaptations to different micro-habitats linked to different types of host plants (herbaceous, shrubby and arboreal) (Tsolakis et al. 1997). As an example Amblyseius cucumeris (Oudemans) showed a better predaceous activity when living on Trifolium spp. or on other herbaceous plants than when living on arboreal plants (Anderson and Morgan 1958).

\section{Climatic adaptations}

Climatic conditions in the various Mediterranean regions range from the subtropical climate of African coasts and of southern European areas (Sicily, Crete, etc.) to the more humid and cooler climate of northern Mediterranean coasts. Microclimatic conditions are more important for animals of such a tiny dimension than macroclimatic ones. This was confirmed in our studies on phytoseiid fauna associated with hazelnut in Sicily. We took into account two hazelnut orchards located at the same exposure distant ca $5-6 \mathrm{~km}$ from each other and at two different altitudes $(500$ and $1000 \mathrm{~m}$ a.s.l.). In both orchards the number of species found was similar (13 and 14 respectively) and some of them were found in both places ( 8 species). The presence of the remaining species as well as the frequency of common species was highly influenced by the microclimatic conditions, by temperatures. In fact, the species we found only at $500 \mathrm{~m}$ (Phytoseius panormita (Ragusa and Swirski), Typhlodromus exhilaratus (Ragusa), Typhlodromus athenas (Swirski and Ragusa)) have been found, up to now, in a warmer climate (Ragusa 1986, unpubl., PapaioannouSouliotis et al. 1994), while the species present only at
$1000 \mathrm{~m}$ (T. pyri, Euseius finlandicus (Oudemans), Typhloseiulus simplex (Chant) are usually typical of a colder climate (Khorkhordin and Losev 1989, Molnàr and Boldog 1989, Duso 1992). Therefore it is not strange to find species such as E. finlandicus, which is a typical species of northern European countries, in warmer regions such as Sicily, Crete and Tunisia. In these latter regions the above species were collected mainly on forest trees on the mountains.

As far as the frequency of the common species is concerned, we saw that the species which showed their dominance at $500 \mathrm{~m}$ were also present at $1000 \mathrm{~m}$ with a smaller frequencies (Tsolakis et al. unpubl.), while some, which were not dominant at $500 \mathrm{~m}$, became dominant at 1000 $\mathrm{m}$.

As far as phytoseiids living in special climatic conditions are concerned, their bodies were subjected to some modifications which enabled them to live in such particular conditions. This was the case of $P$. tamaricis in the Dead Sea, in the Judean desert and central Negev, and of Phytocerus desertorum (Amitai and Swirski) on Acacia in the Negev desert where the weather is very dry and the temperatures' daily range is very wide. A sclerotized and strong dorsal plate is present in these species which covers the whole dorsal surface with thicker setae usually inserted on tubercles. Moreover the dorsal shield and setae are covered by wax in Ph. desertorum (Amitai and Swirski 1978). These adaptations enable the species on the one hand to limit an excessive evaporation of the liquid content of the body during the hot hours of the day, and on the other to protect the individual from inconveniences produced by low night temperatures. 
Similar dorsal shields are also present on other species (T. simplex, Typhloseiulus eliahuswirskii (Ragusa), Typhloseiulus erymanthii (Papadoulis and Emmanouel)) associated with forest plants (Papadoulis and Emmanouel 1988, Ragusa Di Chiara 1991-92, Ragusa Di Chiara et al. 1991) in the cooler climate of the Mediterranean regions. However, if we consider phytoseiid mites living almost at sea level, their tegument is "softer" in comparison to that of the above-mentioned species.

Paragigagnathus tamaricis also showed a reproductive adaptation to climatic conditions. Females are viviparous and this is the first report of viviparity among phytoseiid mites (Amitai and Grinberg 1971). This phenomenon could be seen as an adaptation to the hot and dry climatic conditions as the larval stages have usually a better possibility of survival if compared with eggs which are subjected to dessication.

As far as tetranychid mites of agricultural interest are concerned, no special modifications of the body linked to different climatic conditions are present. However, in $T$. urticae, a species distributed from tropical regions up to northern European countries, some modifications are evident as there are strains with morphological and behavioural characteristics so different that in the past they were considered as belonging to different species (Bolland et al. 1998). For example, we may quote strains of the tropical and subtropical areas, not entering winter diapause, which were identified as Tetranychus cinnabarinus (Boisd.), while strains of temperate areas with cold winters were referred to as T. urticae. Morpho-physiological differences between species with diapause and species without it, are probably due to adaptations of strains to the climatic conditions of the area more than to the seasonal climatic diffferences. Studies were carried out to verify such an hypothesis. Overwintering and aestivating females of $T$. urticae show some morphological differences concerning the cuticle structure: in particular the striae of the tegument present on the dorsal surface in aestivating females are broken and show many triangular or semicircular lobes (Fig. 14), increasing in such a way the surface of evaporation, while striae of overwintering females are not broken to limit the dangers of drying (Boudreaux 1958). Only summer forms were found in our climate.

On the other hand, other species show a limitation in their distribution linked to the climatic conditions. Panonychus citri for instance is a species found in the southern regions mainly associated with Citrus while P. ulmi is present in the northern ones associated with fruit trees and vineyards. It should be noted that $P$. ulmi was also found in Sicily, but in vineyards at high altitudes (mount Etna) where the microclimatic conditions are similar to those of northern and middle Europe (Nucifora and Inserra 1967).

\section{Adaptation to dispersion}

Two types of dispersion can be noticed among tetranychids: a passive one which happens among plants and an active one towards the various parts of the same plant and in the case of herbaceous plants among nearby plants (Brandenburg and Kennedy 1982).

Some tetranichid species show a series of adaptations which facilitate a passive dispersion: 1 ) they hang on silken threads to be more easily carried by the wind as in the case
Fig. 14. Details of cuticle structure of Tetranychus urticae (Koch).

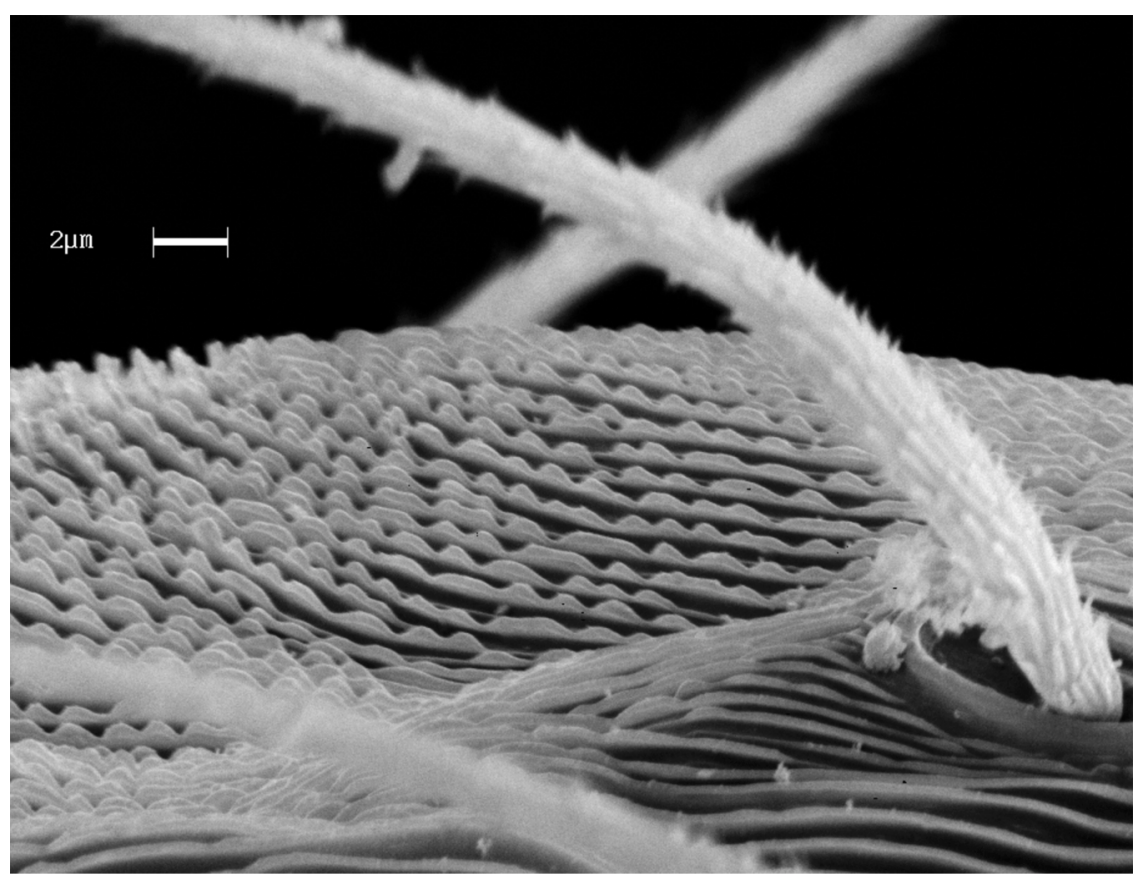


of P. ulmi (parachute threads) (Marlé 1951) and P. citri (silken threads). Oligonychus punicae (Hirst) weaves these silken threads during the night in absence of wind both to be carried by the wind and to reach the leaves or the plants under the trees (Fleschner et al. 1956). The above species, as well as Eutetranychus banksi (McGregor), are scattered in the presence of light gusts of wind. If the wind is strong and continuous, mites do not weave nor migrate (Fleschner et al. 1956, Hoelscher 1967) and migration does not depend on the mites' participation.

2) they raise their first pair of legs to be more easily carried by the wind as in the case of T. urticae. Such a behaviour happens, however, when the wind blows at a speed of at least $1.5 \mathrm{~m} \mathrm{~s}^{-1}$ and under conditions unfavourable to the mites (absence of food and low humidity) (Smitley and Kennedy 1985). Adaptation to dispersion is a prerogative of mated and unmated adult females; young stages seldom get dispersed (most probably because of their small size) and laboratory trials showed that males never assume the position for dispersion (Smitley and Kennedy 1985).

3) If we take phytoseiid mites into account the longdistance dispersion generally happens through air currents as in the case of tetranychids. They assume the same position when they locate the wind direction, or they move towards the most exposed parts of the leaf where there are more possibilities of being carried away by the wind (Sabelis and Dicke 1985). Sabelis and Afman (1984), showed that even if the dispersion is passive, it is the mite that decides when to start its "flight". The dispersion of these predators happens also through deambulation. Phytoseiulus persimilis, for example, is able to move in greenhouses even to $>15 \mathrm{~m}$ from the point of release in a week (Van de Vrie 1985). Phytoseiids disperse also by phoresy: different species have been dispersed by different insects (Treat 1969, Krantz 1973, Grogan and Navai 1975).

Acknowledgements - The authors wish to thank E. De Lillo for allowing them to publish the photos in Figs 9, 10 taken by him, L. Genduso for the using the S.E.M. and E. Chiavetta-Ragusa for reading the English text.

\section{References}

Akimov, I. A. and Starovir, I. S. 1978. Morpho-functional adaptation of difestive system of three species of Phytoseiidae (Parasitiformes, Phytoseiidae) to predatoriness. - Doklady Akad. Nauk Ukranian SSR 7: 635-638, in Russian.

Alberti, G. and Crooker, A. R. 1985. Internal anatomy. - In: Helle, W. and Sabelis, M. W. (eds), Spider mites - their biology, natural enemies and control. Elsevier, 1A, pp. 29-62.

Amitai, S. and Grinberg, T. 1971. Description of a new phytoseiid genus and species (Acarina: Mesostigmata) from Israel. Israel J. Entomol. 6: 327-335.

Amitai, S. and Swirski, S. 1978. A new genus and new records of phytoseiid mites (Mesostigmata: Phytoseiidae) from Israel. Israel J. Entomol. 12: 123-143.
Anderson, N. H. and Morgan, C. V. G. 1958. The role of Typhlodromus spp. (Acarina: Phytoseiidae) in British Columbia apple orchards. - Proc. 10th Int. Congr. Entomol. 4: 659-665.

Blauvelt, W. E. 1945. The internal anatomy of the common red spider mite (Tetranychus telarius Linn.). - Mem. Cornell Univ. Agric. Exp. Stn. Ithaca, NY 270: 1-35.

Bolland, H. R, Gutierrez, J. and Flechtmann, C. 1998. World catalogue of the spider mite family (Acari: Tetranychidae). Leiden, Boston, Koln, Brill.

Boudreaux, H. B. 1958. The effect of relative humidity on egglaying, hatching, and survival in various spider mites. $-\mathrm{J}$. Insect Physiol. 2: 65-72.

Brandenburg, R. L. and Kennedy, G. G. 1982. Intercrop relationships and spider mite dispersal in a corn/peanut agroecosystem. - Entomol. Exp. Appl. 32: 269-276.

Chant, D. A. 1959. Phytoseiid mites (Acarina: Phytoseiidae). Part I. Bionomics of seven species in southeastern England. Part II. A taxonomic review of the family Phytoseiidae, with descriptions of 38 new species. - Can. Entomol. (Suppl. 12) 9: $1-166$

Crowe, J. H. 1975. Studies on acarina cuticles. III. Cuticular ridges in the citrus red mite. - Trans. Am. Microsci. Soc. 94: 98-108.

Duso, C. 1992. Biological control of tetranychid mites in peach orchards of northen Italy: role of Amblyseius andersoni (Chant) and Amblyseius finlandicus (Oud.) (Acari: Phytoseiidae). - Acta Phytopath. Entomol. Hungarica 27(1-4): 211217.

Evans, G. O. 1992. Principles of Acarology. - Cab Int., Cambridge Univ. Press, pp. 563.

Evans, G. O. and Till, W. M. 1965. Studies on the British Dermanyssidae (Acari: Mesostigmata). Part I. External morphology. - Bull. Brit. Mus. (Nat. Hist.) Zool. 13: 249-294.

Flechtmann, C. H. W. and McMurtry, J. A. 1992. Studies on how phytoseiid mites feed on spider mites and pollen. - Int. J. Acarol. 18: 157-162.

Fleschner, C. A. et al. 1956. Air drift of spider mites. - J. Econ. Entomol. 49: 624-627.

Garcia-Marì, F. and Del Rivero, J. M. 1982. El àcaro Tetranychina harti (Ewing) en Espana. - Bol. Serv. Plagas 8: 55-62, in Spanish.

Grogan, W. L. and Navai, S. 1975. New records of mitesassociated with ceratopogonids (Diptera:Ceratopogonidae). - Proc. Entomol. Soc. Wash. 77: 214-215.

Gutierrez, J. and Helle, W. 1985. Evolutionary changes in the Tetranychidae. - In: Helle, W. and Sabelis, M. W. (eds), Spider mites -their biology, natural enemies and control. Elsevier, 1A, pp. 91-107.

Hazan, A., Gerson, U. and Tahori, A. S. 1974. Spider mite webbing. I. The production of webbing under various environmental conditions. - Acarologia 16: 68-84.

Hoelscher, C. E. 1967. Wind dispersal of brown soft scale crawlers, Coccus hesperidum (Homoptera: Coccidae), and Texas citrus mite Eutetranychus banksi (Acarina: Tetranychidae) from Texas citrus. - Ann. Entomol. Soc. Am. 60: 673-678.

Khorkhordin, E. G. and Losev, A. M. 1989. Reaction of the predaceous mite Amblyseius finlandicus to the distribution of the host, the spider mite Schizotetranychus pruni. - Zool. Zh. 68: 38-44, in Russian.

Krantz, G. W. 1973. Dissemination of Kampimodromus aberrans by the Filbert Aphid. - J. Econ. Entomol. 66: 575-576. 
Lindquist, E. E. 1996. External anatomy and notation of structures. - In: Lindquist, E. E. et al. (eds), Eriophyoid mites their biology, natural enemies and control. Elsevier, pp. 331.

Lindquist, E. E. and Oldfield, G. N. 1996. Evolution of eriophyid mites in relation to their host plants. - In: Lindquist, E.E. et al. (eds), Eriophyoid mites - their biology, natural enemies and control. Elsevier, pp. 277-300.

Marlé, G. 1951. Observations on the dispersal of the fruit tree red spider mite, Metatetranychus ulmi (Koch). - Ann. Rep. East Malling Res. Stn. 155-159.

Molnàr, J. G. and Boldog, J. 1989. Studies on the biology of the predatory mite Amblyseius finlandicus Oudemans and on the occurrence of other phytoseiids in vineyards. - Novényvédelem 25: 292-296, in Hungarian.

Nucifora, A. and Inserra, R. 1967. Il Panonychus ulmi (Koch) nei vigneti dell'Etna. - Entomologica 3: 177-236, in Italian.

Nuzzaci, G. 1979. Contributo alla conoscenza dello gnatosoma degli Eriofidi (Acarina: Eriophyoidea). - Entomologica 15: 73-101.

Nuzzaci, G. and De Lillo, E. 1991. Fine structure and functions of the mouth-parts involved in the feeding mechanisms in Tetranychus urticae Koch (Tetranychoidea: Tetranychidae). In: Dusbábek, F. and Bukva, V. (eds), Modern Acarology. Academia, Prague and SPB Academic Publ., The Hague, Vol. 2, pp. 301-306.

Nuzzaci, G. and Alberti, G. 1996. Internal anatomy and physiology. - In: Lindquist, E. E. et. al. (eds), Eriophyoid mites Their biology, natural enemies and control. Elsevier, pp. 101-150.

Nuzzaci, G. et al. 1999. Prosomal glands in Typhlodromus spp. females (Mesostigmata: Phytoseiidae). - In: Bruin, J. et. al. (eds), Ecology and evolution of the acari. Amsterdam, The Netherlands, pp. 637-649.

Pal, R. 1950. The wetting of insect cuticle. - Bull. Entomol. Res. 41: 121-139.

Papadoulis, G. T. and Emmanouel, N. G. 1988. Typhlodromus erymanthii, a new species of the family Phytoseiidae (Acari: Mesostigmata) from Greece. - Entomol. Hellenica 6: 3-6.

Papaioannou-Souliotis, P., Ragusa Di Chiara, S. and Tsolakis, H. 1994. Phytophagous mites and their predators observed on cultivated plants in Greece during 1975-1990. - Ann. Inst. Phytopathol. Benaki (N.S.) 17: 35-87.

Ragusa, S. 1979. Laboratory studies on the food habits of the predaceous mite Typhlodromus exhilaratus. - Adv. Acarol. 1: 485-490.

Ragusa, S. 1986. Study on population fluctuations of phytoseiid mites in a citrus orchard in Sicily. - Acarologia 27: 193-201.

Ragusa Di Chiara, S. 1991-92. Seiulus eliahuswirskii, a new phytoseiid mite (Parasitiformes: Phytoseiidae) living on oak in Sicily. - Israel J. Entomol. 25-26: 23-27.

Ragusa Di Chiara, S., Tsolakis, H. and Russo, A. 1991. Acari fitoseidi associati al renere Quercus in Sicilia, Calabria e Toscana. - Atti Conv. Problematiche fitopat. genere Quercus in Italia, Firenze 19-20 Nov. 1990, pp. 161-169, in Italian.
Ragusa Di Chiara, S. et al. 1995. Acari fitoseidi (Parasitiformes, Phytoseiidae) della Grecia associati a piante forestali a diverse altitudini. - Boll. Zool. Agr. Bachic. Ser. II 27: 85-91, in Italian.

Sabelis, M. W. 1981. Biological control of two-spotted spider mites using phytoseiid predators. Part I. Modelling the predator-prey interaction at the individual level. - Agricult. Res. Rep. 910, Pudoc, Wageningen, The Netherlands.

Sabelis, M. W. and Afman, B. P. 1984. Factors initiating or suppressing aerial dispersal of Phytoseiulus persimilis. - Proc. 17th Int. Congr. Entomol., pp. 445.

Sabelis, M. W. and Dicke, M. 1985. Long-range dispersal and searching behaviour. - In: Helle, W. and Sabelis, M. W. (eds), Spider mites - their biology, natural enemies and control. Elsevier, 1B, pp. 141-160.

Saitô, Y. 1983. The concept of "life types" in Tetranychinae - an attempt to classify the spinning behaviour of Tetranychinae. - Acarologia 24: 377-391.

Smitley, D. R. and Kennedy, G. G. 1985. Photo-oriented aerialdispersal behavior of Tetranychus urticae (Acari: Tetranychidae) enhances escape from the leaf surface. - Ann. Entomol. Soc. Am. 78: 609-614.

Starovir, I. S. 1973. Some singularities in the structure of digestive and excretory systems in Phytoseiulus persimilis AthiasHenriot (Parasitiformes, Phytoseiidae). - Vest. Zool. 5: 7277 , in Russian.

Takafuji, A. and Chant, D. A. 1976. Comparative studies of two species of predacious phytoseiid mites (Acarina: Phytoseiidae), with special reference to their responses to the density of their prey. - Res. Popul. Ecol. 17: 255-310.

Treat, A. E. 1969. Behavioral aspects of the association of mites with noctuid moths. - Proc. 2nd Int. Congr. Acarol., Sutton Bonington, England, pp. 275-1089.

Tsolakis, H. and Ragusa Di Chiara, S. 1994. Biological and life table parameters of Amblyseius andersoni (Chant) (Parasitiformes, Phytoseiidae) on different kinds of food substances. - Phytophaga 5: 21-28.

Tsolakis, H., Ragusa, E. and Ragusa, S. 1997. Importanza della flora spontanea ai margini degli agroecosistemi per gli acari fitoseidi (Parasitiformes, Phytoseiidae). - Naturalista sicil. S. IV, XXI (Suppl.): 159-173.

Van de Vrie, M. 1985. Control of tetranychids in crops - Greenhouse ornamentals. - In: Helle, W. and Sabelis, M. W. (eds), Spider mites - their biology, natural enemies and control. Elsevier, 1B, pp. 273-283.

Witul, A. and Kielkiewicz, M. 1999. Life-history parameters of two closely related forms of the Tetranychus urticae-complex on different host plants. - In: Bruin, J. et. al. (eds), Ecology and evolution of the acari, Amsterdam, The Netherlands, pp. 399-404. 